\title{
Alternative Techniques for Teaching Writing
}

\author{
Sihindun Arumi \\ English Department of Veteran Bangun Nusantara University of \\ Sukoharjo \\ Jl. Letjend. Humardani no. 1 Jombor, Sukoharjo \\ arumisihindun@yahoo.com
}

\begin{abstract}
Writing as one of language skill is often considered very difficult. It is due to the fact that writing needs to produce and organize ideas using appropriate vocabulary, language use, paragraph organization, and mechanism. It also needs to turn the ideas into a readable text and for foreign language learners; they should also transfer ideas from their native language into target language (foreign language). It raises any problems for them to create a good text. Moreover, the situation in the class does not always support them in which the techniques of the teacher in teaching writing are boring and monotonous; it do not give enough attention to help students explore their writing skills. So that they attend the writing class only for procedural formality.Thus, it is considered important to elaborate various techniques to build nice classroom atmosphere as well as to improve students' writing skills.
\end{abstract}

Key words: Alternative, Technique, Writing. 


\begin{abstract}
Abstrak
Menulis sebagai salah satu keterampilan bahasa sering dianggap sangat sulit. Hal ini disebabkan oleh fakta bahwa menulismemerlukan penciptaan dan pengaturan ide-ide menggunakan kosa kata, penggunaan bahasa, pengaturan paragraf, dan mekanisme yang sesuai.Hal ini juga memerlukan untuk mengubah ide-ide kedalam teks yang enak di baca dan bagi pembelajarbahasa asing, mereka juga harus mentransfer ide-ide dari bahasa asli mereka ke dalam bahasa sasaran (bahasa asing).Hal ini menimbulkan masalah bagi mereka untuk menciptakan teks yang baik. Selain itu, situasi di kelas tidak selalu mendukung mereka ketika teknik guru dalam pengajaran menulis membosankan dan monoton, tidak memberikan perhatian yang cukup untuk membantu siswa mengeksplorasi kemampuan menulis mereka. Sehingga mereka menghadiri kelas menulis hanya untuk formalitas prosedural. Dengan demikian, penting untuk dipertimbangkan untuk memaparkan berbagai teknik untuk membangun suasana kelas yang baik serta meningkatkan kemampuan menulis siswa.
\end{abstract}

Kata kunci: Alternatif, Teknik, Menulis

\title{
Introduction
}

Language as a means of communication involves four skills, namely listening, speaking, reading, and writing. As one of the skills, writing takes important role in language learning. It is needed to learn by people for their occupational or academic purpose. For example, for business, people need to write business letters, like order, complaint, request letters, etc.; for seeking job, they need to make application letters; for carrying out events, they need to write proposals, etc. While for students, for their academic purposes, need to learn writing for preparing final academic assignment, namely thesis writing. Thus, writing is a crucial need for people for their own purposes. 
However, among the four skills, writing is generally considered more difficult for most people. It may be due to the fact that writing as a kind of active or productive skill needs to produce and organize ideas using appropriate of vocabulary, sentences and paragraph organization. It also needs to turn the ideas into a readable text (Richard \& Renandya, 2002). Especially for most foreign language learners, they should also transfer ideas from their native language into target language (foreign language).

They may be the reasons that raise a phenomenon that writing activity appears as a not-live activity. The students are not motivated to attend the writing activity. It seems that they join the writing class only for an attendance requirement. They only come, sit and listen to the teacher's explanation, and do the exercises without doing any progress activity. They feel that writing is a big problem. They get difficulty in generating ideas, in addition, the teacher style in teaching writing is assumed boring and conventional. They just explain the material, give exercises, and finish the meeting continued by correcting the piles of students' assignments. Thus, it is considered important to elaborate various techniques or strategies in writing activity to encourage students' enthusiasm and activeness. It is also to help teachers manage a joyful classroom activities and atmosphere to support students' writing activities.

\section{Concept of Writing}

Writing is such a productive skill that means it produces a sequence of sentences arranged in a particular order and linked together in certain ways (Harmer, 1983). The sequence maybe short, two, or three 
sentences, or more sentences put in order and linked together forming a coherent whole called as text (Byrne, 1997). It can be also said as an act of forming graphic symbols, or making marks on flat surface. Graphic symbols are the combinations of letters which related to the sounds the people make when they speak. These symbols have to be arranged, according to certain conventions to form words, and words have to be arranged to form sentence (Byrne, 1997). The activity of arranging sentences belongs to a cognitive activity. As an extremely complex cognitive activity, writing requires to demonstrate control of a number of variables (Bell and Burnaby, 1984 in Nunan (1999). Above of all, writing is a way of communicating a message to a reader for a purpose (Troyka, 1987).

Writing activity is carried out in various ways. The ways can represent what approach that is used. In general, writing process can be categorized into two approaches, namely products approach and process approach. Product approach focuses on the end result of the learning process. It expects the learners to be able to do as a fluent and competence user of the language (Brown, 2000). On the other hand, process approach emphasizes on the various classroom activities which are believed to promote the development of skilled language use (Nunan, 1999).

\section{Product Approach}

Product approach is considered as a traditional way of teaching writing. It pushes the product or result. In this application, the learners are given only very little attention to help them develop their ideas in writing process. Then, dull, dry, and boring situation colors the writing 
activity (Leki, 1996). The teacher usually provides a model and encourages the students to imitate it to produce similar product. The procedures include imitating, copying, and transferring models provided by the teacher and emphasizing the error free final product (Nunan, 1999). Then, catching grammar, spelling, and punctuation errors is the main purpose of writing activity in this approach (Leki, 1996). Most of the students' activity tends to be guided writing in which they mostly do grammar exercise. The writing products are considered goof if they are free of or have only few errors. Then the students write very carefully in the foreign language to hinder the errors.

Writing activity using product approach is began by having students use notes to write complete sentences, following a given model, then it is continued by reading a model of text and having students produce similar text (Long and Richards, 1990). The purpose of the activity is a final product of writing and what it should look like. The traditional criteria for good writing based on product approach is meeting certain standards of prescribed English rhetorical style, reflecting accurate grammar, and be organized in conformity with what the audience would consider to be conventional (Brown, 2000). Then, the main focus is given to model composition that students imitate and how well their final product to meet the criteria of good writing involving content, organization, vocabulary, grammar use, and mechanic like spelling and punctuation. This approach seems not too satisfying until it leads to the second approach. 


\section{Process Approach}

Process approach proposes more effective classroom activities to help students develop their ability to convey meaning and content that they want to express in their text. This approach argues that the process model can help students to discover what they want to write as that more successfully for this approach is considered as writer centered (Walsh, 2004). This approach does not press students to do grammar exercises but rather explores strategies to help students elaborate their ideas. Students will be encouraged to write what they want to communicate.

However, between product and process should be treated in a balance way. Final product is important but the writing process should be more exploratory, less punitive, less demoralizing, and the students are less alone (Leki, 1996).The product should be the result of writing process of prewriting, drafting, revising, and editing (Brown, 2000). Prewriting as the firt stage is gathering ideas. It is continued by the second step, drafting that is writing a rough draft outline. The next is revising to modify the draft based on the feedback after reading the draft again and sharing with others to get comments. The last is editing that is correcting mechanical errors like spelling or punctuation.

Classroom activity in process approach can be carried out in six steps (Fauziati, 2010). The first, writing process should focus on the instruction. It means that the students can initiate into the process and the teacher should prepare to intervene in the students' writing processes with suggestions and correction to help them overcome difficulties encountered in each of the stages. Second, the assigned writing tasks should encourage students to write a variety of modes besides expository 
writing. Third, conferencing is an important part of classroom activities between teacher and students as well among students to provide students with immediate meaningful responses to their writing. Fourth, the main role of teacher is as a facilitator, in which he should not focus just on errors in the product, but is free to respond to a number of facets of students' writing. Fifth, students should be able to work and help each other. The last, it should be able to encourage a bond to tie all members of the class into one community whose each member feels responsible for each other's growth. Then, the writing process needs any techniques or strategies to encourage students to develop themselves in writing activities.

\section{Alternative Techniques for Teaching Writing}

As a process of progress - oriented, writing requires the writers to follow the stages of writing process to result in good products. Good writing can be seen from the completeness, unity, and coherences. Thus, a good writing should consider the content, organization, language use or grammar, vocabulary, andmechanic like capitalization, punctuation, spelling,, etc. However, it needs process to achieve a good result. It can be realized by exploring various ways or strategies or techniques.

\section{Guided Questions}

It is a kind of techniques in which students write after given any questions about the topic (Silberman, 2006). It belongs to a simple technique because students are still guided by the teacher with questions. It purposes to give students any description about the topic, especially for abstract one. It also gives any background knowledge and vocabularies 
relating to the topic. Then, it is hoped to be able to help students explore the topic in their writing activity.

There are any steps to do the guided questions technique. The first, teacher determines the topic. Then he prepares a number of questions to open the mind and knowledge of the students. The questions are considered to have several possible answers. Next, teacher gives students a few moments to consider their responses. It can be done either individually or in pairs or groups. Afterward, the teacher may combine the responses of the entire class and record their ideas.

If possible, he can choose students' responses into a separate list relating to the categories or the different concepts that teacher tries to teach. Next, teacher presents the main learning points which he wants to teach by asking students to describe how their responses fit with these points. The ideas can be recorded to add the learning points of the material. From the activity, the students can start writing process. For example, if you want to teach descriptive text, firstly you can explain about descriptive text and give a model. Then you determine a topic to write, as example is 'Favorite Teacher". You can explore any questions about the students' favorite teacher, like 'Who is your favorite teacher?', 'What is his/ her name?', 'Why do students like her/ him?', 'Where does she/ he live?', etc. Each question will be answered orally and then written by the students on their papers. The variations of this technique can be done in pairs or groups. It can be also done individually in the form of written questions answered by the students themselves. Teacher can manage variations of this technique to allow students explore their writing skill. 
This technique has an advantage to provide students with background knowledge, description, and vocabulary about the topic to start writing activity since in the beginning, many of them have no ideas or get blank in their mind when they should have writing activity. However, this technique requires to arrange the questions consecutively based on sequential ideas.

\section{Connected Sentences}

Connected sentences are a technique that involves all the members of the class in writing activity. It is begun by determining the topic followed by building background knowledge including description, vocabularies, and language use. Then, the teacher asks the first student to write a sentence based on the topic on the white board. It should be continued by other students until all students in the class have written one sentence of each. After that, the teacher discusses the students' sentences. It can be modified by working in groups of 4 or 5 students and do the same step of connected sentences. After finish, the groups exchange their works of writing and each group should edit other groups' work. Next, each group presents the result of editing of other groups' works and teacher manage the activity by giving comments, suggestions, or advices. In this case, students cannot only write but also edit friends' works.

This technique has an advantage to let all students participate in writing activity. However, it may be quite difficult to cover all students' sentences since they make sentences based on their experiences and knowledge. So, little not-synchronized sentences may occur. 


\section{Index Card Match}

Index card match is a kind of technique matching cards to find the pairs of the cards. It is an active and fun way to recall the material that is given (Silberman, 2006). It will help students actively participate in writing process. It will also help the class atmosphere cheerful and pleasant, and sometimes a bit noisy.

The characteristic of index card match using cards. The cards are divided into two parts, questions and answers. It is done in pairs. The activities of this technique are started by providing cards as many as the number of the students in the class. Then, on separate cards, write down questions about anything taught in the class. Create enough cards for questions to equal one half of the number of students. Try to choose questions that have brief, focused answer. On other separate cards, write the answers of the questions. Next, mix the two sets of cards and shuffle them several times so that they are well-mixed. After that, share one card to each student. Ask the students getting question cards to sit down and write their answers of the question on their cards, while students getting answer cards stand up in front of the class. The students are given certain time to finish their writing answers. Then instruct students getting questions to state their answers and students getting answers to open their cards. Have them to find their match. After they find their match, suggest them so have seats together but tell them not to reveal what is contained on their cards to other friends. When everyone is seated, have each pair of cards then read out question and answer in class. The next activity is listing all points or ideas presented in questions and answers and students may start the writing activity. 


\section{Quiz Team Technique}

Quiz Team Technique is a technique for writing activity by giving quiz or questions to the students working in groups. After the teacher delivers the material, the students are divided into, for example, three big groups. They all should learn the rule of the quiz. All group should also prepare any questions about the material taught by the teacher that will be asked to other groups. The first group will have the initial turn to give questions to the second group. If the second group cannot answer, it will be delivered to the third group. If the first session of quiz finishes, then second group takes the turn to be the questioner continued by the third group. The same questions should not be asked repeatedly to other groups. Each group should make notes about the questions addressed to it, completed with the correct answers from other group. After all groups finish giving quiz, teacher helps draw conclusion and have students start writing activity based on the notes they make.

This technique may help students focus on the topic discussed for they shoul make any questions that will be given to other groups. This led to their seriousness. It may also help students develop their creativity. However, it needs enough time to conduct this technique. It also requires strict control in conditioning the class when the quiz is conducted. Besides, it needs to spread the smart students fairly to the groups because this technique requires quick responses to the quiz.

\section{Think - Pair - Share}

Think - Pair - Share is a kind of technique to have activities of thinking about a problem then working in pair or group to solve the 
problem, and sharing the works in the class. This technique can help students work individually as well as in group. It also train student's process information, communicates, and develops stronger thinking skill.

This technique can be applied when the teacher presents a topic or problem after delivering his material. The teacher gives the students time for thinking about the topic or problem individually. Then students are asked to make pairs. They are allowed to discuss their opinion or ideas about the topic or problem with their partners. Then they write the result of their discussion. After that, they share the result of their discussion that they have written in the class. Next, teacher and students discuss it together.

This technique permits students to learn from other students by discussing a topic after thinking individually. It also helps students build their self-confidence when sharing and expressing their opinion. However, it needs a good management of time in applying this technique.

\section{Conclusion}

Writing is a kind of active or productive skill so that it needs to produce a series of sentences to form a good text. To produce a readable text, it needs not only an interesting content but also various vocabularies, grammatical language use as well as paragraph organization and mechanism, like spelling and punctuation. However, techniques in writing activity are also very important that they should be able to encourage students in writing activity. The techniques should give chance and attention to the students in writing activity in order that they 
can explore and improve their writing competence. Thus various techniques or strategies should be tried to apply in writing activity, either for individual or group works. 


\section{References}

Brown, H. D. 2000. Principles of Language Learning And Teaching. New York: Longman.

Brown, H. Douglas. 2000. Teaching by Principle: An Interactive Approach to Language Pedagogy. New: Prentice Hall Regents.

Bryne, Donn. 1997. Teaching Writing Skills. London: Harlow, Essex: Longman

Fauziati, Endang. 2010. Teaching English as Foreign Language (TEFL). Surakarta: Muhammadiyah University Press.

Harmer, Jeremy. 1983. The Practice of English Language Teaching. London: Longman.

Leki, Ilona. 1996. "Teaching Second Language Writing: "Where We Seem To Be" In Kral, Thomas (Ed) 1996. Teacher Development: Making the Right Moves.

Long, Michael H. \& Jack C. Richard. (Eds). 1987. Methodology in TESOL. New York: New Bury House..

Nunan, D. 1999. Second Language Teaching and Learning. Boston: Heinle \& Heinle.

Silberman, Melvin. 2006.101 Ways to Make Training Active. Second Edition. United Stated of America: Pfeiffer. 